\title{
Metallacarboranes: New synthetic strategies and structural patterns*
}

\author{
Narayan S. Hosmane ${ }^{1, \ddagger}$ and John A. Maguire ${ }^{2}$ \\ ${ }^{1}$ Department of Chemistry and Biochemistry, Northern Illinois University, DeKalb, \\ IL 60115-2862, USA; ${ }^{2}$ Department of Chemistry, Southern Methodist University, \\ Dallas, TX 75275, USA
}

\begin{abstract}
A summary of the latest results in the authors' laboratories covering three areas is presented. The results of the controlled syntheses of oxide ion encapsulating lanthanacarboranes, by the introduction of stoichiometric amounts of $\mathrm{H}_{2} \mathrm{O}$ in the synthesis reactions, and the strictures of the resulting compounds were discussed. The scope and limitations of a general method for the synthesis of the open pentadienyl complexes were presented. In addition, the results of a systematic study of the reactions of the $\left[2, n-\left(\mathrm{SiMe}_{3}\right)_{2}\right.$-nido$\left.2, n-\mathrm{C}_{2} \mathrm{~B}_{4} \mathrm{H}_{4}\right]^{2-}(n=3,4)$ with the late transition-metal salts $\mathrm{MCl}_{2}(\mathrm{M}=\mathrm{Fe}, \mathrm{Co}, \mathrm{Ni})$ were discussed.
\end{abstract}

Keywords: metallacarboranes; lanthanacarboranes; open pentadienyl complexes; carbaborane cages; carbaboranes.

\section{INTRODUCTION}

In recent years, there has been an upsurge of interest in the compounds formed when main group, $d$ - and $f$-block metals are incorporated in carborane or carbaborane cages [1-3]. Two of the most extensively studied metallacarboranes are those based on the icosahedral $\left(\mathrm{MC}_{2} \mathrm{~B}_{9}\right)$ and pentagonal bipyramidal $\left(\mathrm{MC}_{2} \mathrm{~B}_{4}\right)$ cage systems. The former is the oldest and most cited, but the latter is not far behind [2]. The original, and current, interest in these compounds stems from the recognition in 1965 by Hawthorne and coworkers that the filled frontier orbitals on the $\mathrm{C}_{2} \mathrm{~B}_{3}$ open face of $\left[\text { nido- } \mathrm{C}_{2} \mathrm{~B}_{9} \mathrm{H}_{11}\right]^{2-}$ were quite similar to the primary metal bonding orbitals in the cyclopentadienide $\left[\mathrm{C}_{5} \mathrm{H}_{5}\right]^{-}(\mathrm{Cp})$ ion [4]. This similarity has been verified, both theoretically and experimentally; a number of mixed-, full- and half-sandwich complexes involving this ligand have been synthesized and characterized [2]. The [nido- $\left.\mathrm{C}_{2} \mathrm{~B}_{4} \mathrm{H}_{6}\right]^{2-}$ ion also has a $\mathrm{C}_{2} \mathrm{~B}_{3}$ pentagonal face in which 6 electrons are delocalized in $\pi$-type orbitals similar to the $\mathrm{Cp}$ ligand and forms analogous complexes. There are two possible arrangements of the atoms in the $\mathrm{C}_{2} \mathrm{~B}_{3}$ face, one in which the two carbons atoms occupy adjacent positions, the "carbons-adjacent" isomer, and another in which the two atoms are separated by a boron, the "carbons-apart" isomer. Both seem to bond metals equally well, but the latter one is thermodynamically more stable. Sometimes this increased stability can determine the course of the metallation reactions.

\footnotetext{
*Paper based on a presentation at the $12^{\text {th }}$ International Meeting on Boron Chemistry (IMEBORON-XII), Sendai, Japan, 11-15 September 2005. Other presentations are published in this issue, pp. 1299-1453.

¥Corresponding author
} 


\section{SYNTHESES AND STRUCTURES OF $\boldsymbol{f}$-BLOCK METALLACARBORANE CLUSTERS CONTAINING ENCAPSULATED OXIDE IONS}

Our interest in oxo-lanthanide compounds stems from our previous observation that, unlike the $\mathrm{C}_{2} \mathrm{~B}_{9}$ and $\mathrm{C}_{2} \mathrm{~B}_{10}$ ligands, the $\mathrm{C}_{2} \mathrm{~B}_{4}$-carboranes could form unusual oxo-lanthanacarboranes of the type $\left\{\left[\eta^{5}-1-\mathrm{Ln}-2,3-\left(\mathrm{SiMe}_{3}\right)_{2}-2,3-\mathrm{C}_{2} \mathrm{~B}_{4} \mathrm{H}_{4}\right]_{3}\left[\left(\mu-1-\mathrm{Li}-2,3-\left(\mathrm{SiMe}_{3}\right)_{2}-2,3-\mathrm{C}_{2} \mathrm{~B}_{4} \mathrm{H}_{4}\right)_{3}\left(\mu_{3}-\mathrm{OMe}\right)\right]-\right.$ $\left.[\mu-\mathrm{Li}(\mathrm{THF})]_{3}\left(\mu_{3}-\mathrm{O}\right)\right\}(\mathrm{Ln}=\mathrm{Nd}, \mathrm{Sm}, \mathrm{Gd}, \mathrm{Tb}, \mathrm{Dy}$, and Ho] [6-8]. The compounds were obtained from the reaction of the THF-solvated dilithium salt of the $\left[2,3-\left(\mathrm{SiMe}_{3}\right)_{2} \mathrm{C}_{2} \mathrm{~B}_{4} \mathrm{H}_{4}\right]^{2-}$ dianion with anhydrous $\mathrm{LnCl}_{3}$ in a molar ratio of 2:1 in dry benzene and THF [7]. The first synthesis was completely unexpected, but was repeatable with a number of different $\mathrm{LnCl}_{3}$ salts, as shown in Scheme 1. In retrospect, these clusters most likely arise from an initial formation of a half-sandwich lanthanacarborane that then reacts with THF or its decomposition product to form the final cluster. This assumption is bolstered by the observation that the TMEDA-solvated dilithium salt of $\left[2,3-\left(\mathrm{SiMe}_{3}\right)_{2} \mathrm{C}_{2} \mathrm{~B}_{4} \mathrm{H}_{4}\right]^{2-}$ at $2: 1$ carborane to $\mathrm{LnCl}_{3}$ molar ratios produced the expected full-sandwich lanthanacarboranes, [1-Cl-1- $(\mu-\mathrm{Cl})-2,2^{\prime}, 3,3^{\prime}-$ $\left(\mathrm{SiMe}_{3}\right)_{4}-5,6-\left[(\mu-\mathrm{H})_{2} \mathrm{Li}(\mathrm{TMEDA})\right]-4,44^{\prime}, 5,5^{\prime}-\left[\left(\mu-\mathrm{H}_{3}\right) \operatorname{Li}(\mathrm{TMEDA}) \text {-commo- } \operatorname{Ln}\left(2,3-\mathrm{C}_{2} \mathrm{~B}_{4} \mathrm{H}_{4}\right)_{2}\right]^{-}(\mathrm{Ln}=$ $\mathrm{Sm}, \mathrm{Gd}, \mathrm{Dy}, \mathrm{Ho}$, and Er) [9]. Since the reaction leading to the trinuclear clusters is evidently a complex one, this led us to question whether there could be more direct, alternative methods to synthesize oxolanthanacarboranes routinely.

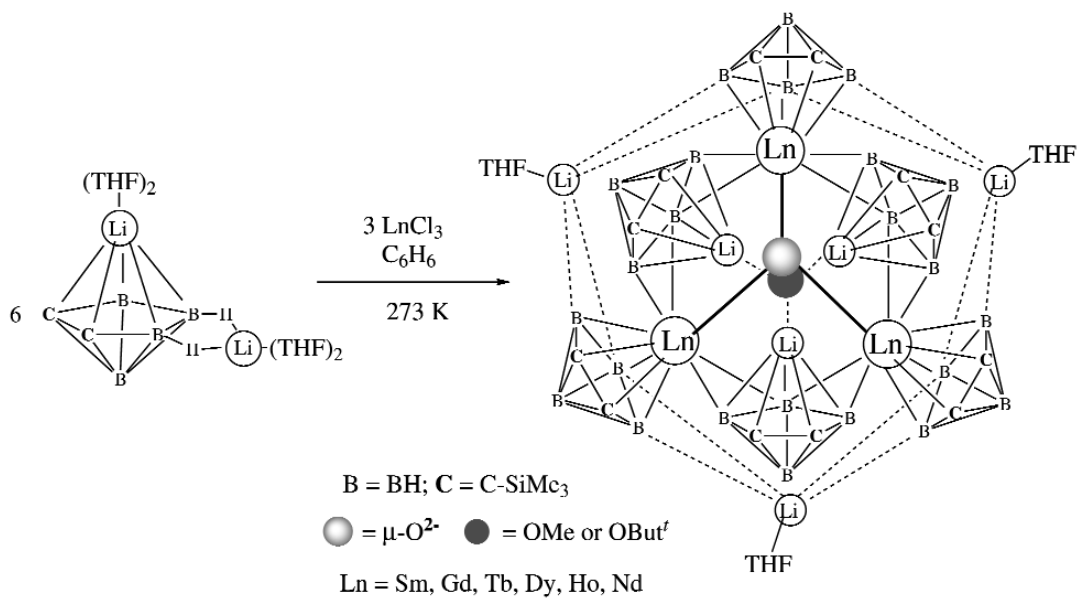

Scheme 1 Synthesis of trinuclear lanthanacarborane clusters.

Consequently, we have explored a new synthetic approach to the oxide ion-encapsulating tetralanthanide tetrahedra that are also complexed with the carbons-apart $\mathrm{C}_{2} \mathrm{~B}_{4}$-carborane ligands (see Scheme 2). In this synthesis, anhydrous $\mathrm{LnCl}_{3}(\mathrm{Ln}=\mathrm{La}, \mathrm{Nd}, \mathrm{Gd}, \mathrm{Tb}, \mathrm{Ho}$, and $\mathrm{Lu}$ ) was first treated with distilled water under refluxing conditions in THF. The closo-exo-5,6-Na(THF) ${ }_{2}-1-\mathrm{Na}(\mathrm{THF})_{2}-2,4-$ $\left(\mathrm{SiMe}_{3}\right)_{2}-2,4-\mathrm{C}_{2} \mathrm{~B}_{4} \mathrm{H}_{4}$ was then mixed with the refluxed solution of the lanthanide reagent at $-78^{\circ} \mathrm{C}$ to give the oxo-lanthanacarboranes, $\left\{\left[\eta^{5}-1-\mathrm{Ln}(\mathrm{THF})_{n}-2,4-\left(\mathrm{SiMe}_{3}\right)_{2}-2,4-\mathrm{C}_{2} \mathrm{~B}_{4} \mathrm{H}_{4}\right]_{4}(\mu-\mathrm{Cl})_{2}\left(\mu_{4}-\mathrm{O}\right)\right\} \cdot(\mathrm{THF})_{y}$ $[\mathrm{Ln}=\mathrm{La}, n=0, y=1 ; \mathrm{Nd}, n=1, y=0 ; \mathrm{Gd}, n=0, y=1 ; \mathrm{Tb}, n=1, y=0 ; \mathrm{Ho}, n=0, y=1 ; \mathrm{Lu}, n=1$, $\mathrm{y}=0$ ] in $73-86 \%$ yields [10]. The core structure of one of the complexes, where $\mathrm{Ln}=\mathrm{Ho}$, is shown in Fig. 1. The reactions are very sensitive to both stoichiometry and procedure: the $\mathrm{LnCl}_{3} / \mathrm{H}_{2} \mathrm{O} / \mathrm{THF}$ mixture must be refluxed until a homogeneous solution is obtained and the reactions must be carried out initially at $-78{ }^{\circ} \mathrm{C}$ and then completed at reflux temperatures. If $\mathrm{LnCl}_{3}$ and $\mathrm{H}_{2} \mathrm{O}$ were added to a solution of the carborane ligand without prior refluxing, the water directly attacked and rapidly decomposed the carborane ligand. The best yields were obtained from "exact" stoichiometric mixtures, assuming one carborane dianion acts as a proton scavenger; there is NMR evidence for the formation of a neutral 
nido-carborane in the final reaction mixture. A 1:1 carborane:Ln molar ratio led to the same products, but in lower yields. In addition, reactions in which the $\mathrm{Ln}_{\mathrm{H}} \mathrm{O}$ O ratios were less than $4: 1$ resulted in the formation of inseparable product mixtures, while higher ratios produced the tetralanthanide clusters and the unreacted carborane precursor [10]. Although a number of $\mathrm{Ln}_{4} \mathrm{O}$ clusters are known, their geometries are varied, encompassing tetrahedral [10,11], planar [12], and butterfly-shaped [13]. Since density functional theory (DFT) results on the model compound $\mathrm{La}_{4} \mathrm{OCl}_{2}\left(2,4-\mathrm{C}_{2} \mathrm{~B}_{4} \mathrm{H}_{6}\right)_{4}\left(\mathrm{OH}_{2}\right)_{4}$ show essentially ionic interactions [10b], the various shapes must arise from complex interactions involving not only the nature of the lanthanide but also the influence of the other ligands and the synthetic procedures. The systematic synthetic approach of using $\mathrm{H}_{2} \mathrm{O}$ as one of the controlled reagents led to the construction of hitherto unexplored lanthanacarborane clusters comprising a $\left[\left(\mathrm{C}_{2} \mathrm{~B}_{4} \mathrm{Ln}\right)_{4} \mathrm{Cl}_{2} \mathrm{O}\right]$ core.

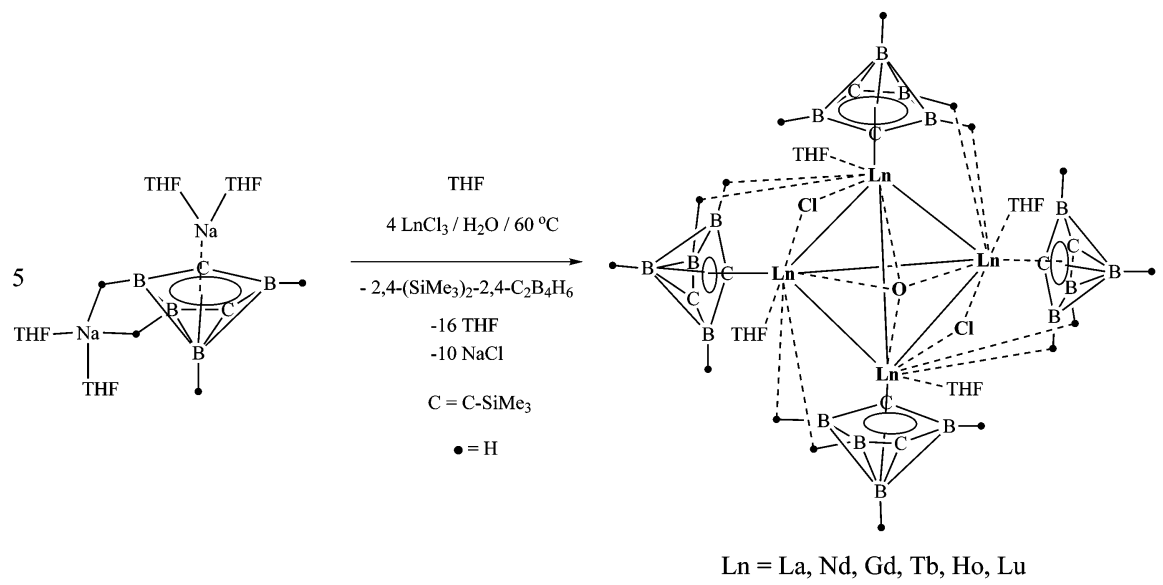

Scheme 2 Synthesis of the oxo-lanthanacarborane clusters.

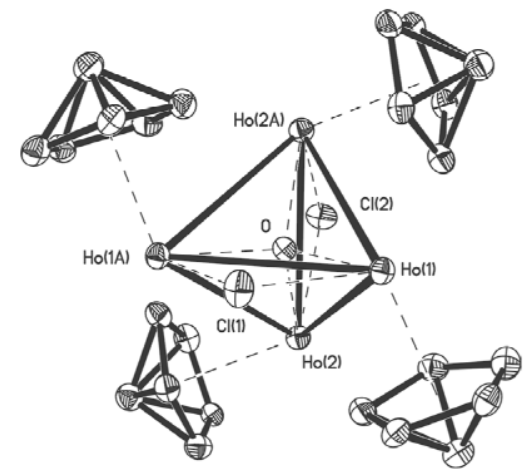

Fig. 1 The $\left[\left(\mathrm{C}_{2} \mathrm{~B}_{4} \mathrm{Ho}\right)_{4} \mathrm{Cl}_{2} \mathrm{O}\right]$ core of the oxo-lanthanacarborane cluster.

\section{SYNTHESES AND STRUCTURES OF OPEN-PENTADIENYL METALLACARBORANE COMPLEXES}

In addition to the well-studied cyclopentadienyl ligand, there is another six $\pi$-electron donor, the openpentadienyl ligand, $\mathrm{R}_{7} \mathrm{C}_{5}$, $(\mathrm{R}=\mathrm{H}$ or an alkyl derivative). A number of so-called "open-metallocenes" where the pentadienyl group replaces one or more cyclopentadienyl ligands have been synthesized and characterized [14]. The pentadienyls have been shown to be similar to their cyclic analogs in some respects, but possess a unique chemistry that has led to a number of unusual compounds, such as the 
metallabenzenes and their $\pi$-complexes $[15,16]$. We have explored the syntheses of the mixed open pentadienyl metallacarboranes by synthesizing the complexes, $\left[\left(\eta^{5}-2,4-(\mathrm{Me})_{2} \mathrm{C}_{5} \mathrm{H}_{5}\right)\left(\eta^{5}-2,3-\left(\mathrm{Me}_{3} \mathrm{Si}_{2}{ }_{2}-\right.\right.\right.$ 2,3- $\left.\left.\mathrm{C}_{2} \mathrm{~B}_{4} \mathrm{H}_{4}\right) \mathrm{Ln}\right]_{2}(\mathrm{Ln}=\mathrm{Tb}, \mathrm{Er})$, by reacting the neutral 2,3- $\left(\mathrm{SiMe}_{3}\right)_{2}-$ nido-2,3- $\mathrm{C}_{2} \mathrm{~B}_{4} \mathrm{H}_{6}$ in a 1:1 molar ratio with $\mathrm{Ln}\left(2,4-(\mathrm{Me})_{2} \mathrm{C}_{5} \mathrm{H}_{5}\right)_{3}$ in a two-step process as outlined in Scheme 3 [17]. The crystal structures (see Fig. 2, $\mathrm{Ln}=\mathrm{Tb}$ ) show that each compound crystallizes as a dimer in which a pentadienyl and a carborane ligand are $\eta^{5}$-bonded to a metal atom. In addition, each carborane is $\eta^{2}$-bonded to a neighboring metal in the dimer [17].

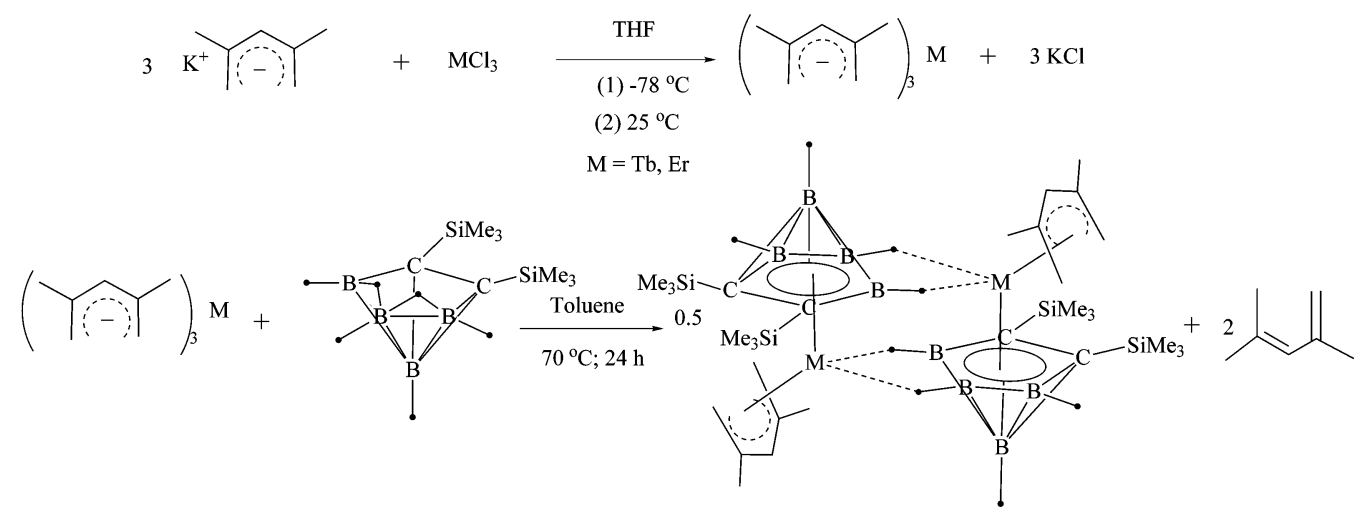

Scheme 3 Synthesis of the open-pentadienylmetallacarboranes.

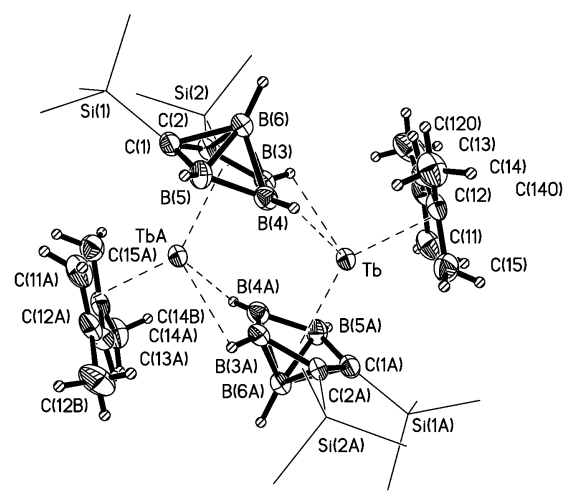

Fig. 2 Dimeric open-pentadienylmetallacarboranes.

The synthesis takes advantage of the higher acidity of the bridged H's in nido-2,3- $\left(\mathrm{SiMe}_{3}\right)_{2}-2,3-$ $\mathrm{C}_{2} \mathrm{~B}_{4} \mathrm{H}_{6}$ compared to the methylene hydrogens on the neutral pentadiene, 2,4-(Me) ${ }_{2} \mathrm{C}_{5} \mathrm{H}_{6}$. Thus, the "diprotic" nido-2,3-( $\left.\mathrm{SiMe}_{3}\right)_{2}-2,3-\mathrm{C}_{2} \mathrm{~B}_{4} \mathrm{H}_{6}$ removes two [2,4-(Me) $\left.{ }_{2} \mathrm{C}_{5} \mathrm{H}_{5}\right]^{-}$ligands by protonation on the tris(pentadienyl)lanthanide, leading to the mixed-ligand products. Since the metal played somewhat of a passive role, it was assumed that the synthesis method was a general one that could be applied to all the lanthanides; this turned out not to be the case. It was found that the synthesis outlined in Scheme 3 works well for the later lanthanide metals $(\mathrm{Ln}=\mathrm{Gd}, \mathrm{Tb}, \mathrm{Dy}, \mathrm{Ho}, \mathrm{Er}, \mathrm{Tm}, \mathrm{Lu})$, but it did not work for the earlier ones $(\mathrm{Ln}=\mathrm{La}, \mathrm{Ce}, \mathrm{Pr}, \mathrm{Nd}, \mathrm{Sm})$ [18]. The corresponding $\left[\left(\eta^{5}-2,4-(\mathrm{Me})_{2} \mathrm{C}_{5} \mathrm{H}_{5}\right)\left(\eta^{5}-2-\right.\right.$ $\left.\left.\left(\mathrm{Me}_{3} \mathrm{Si}\right)-3-(\mathrm{Me})-2,3-\mathrm{C}_{2} \mathrm{~B}_{4} \mathrm{H}_{4}\right) \mathrm{Ln}\right]_{2}$ were obtained in the same way [18]. These studies are continuing to ascertain the reasons for the method's limitation. 


\section{REACTIONS OF THE LATE TRANSITION METALS WITH SMALL-CAGE CARBORANES}

The behavior of the late transition metals toward the small-cage nido-carboranes complexes depends on the thermodynamic stabilities of the isomeric form of the nido- $\mathrm{C}_{2} \mathrm{~B}_{4}$ carborane. This was demonstrated by the reactions of anhydrous $\mathrm{NiCl}_{2}$ with the two isomeric nido- $\mathrm{C}_{2} \mathrm{~B}_{4}$ carboranes. The reaction with the dilithium-complexed carbons-adjacent nido-carborane dianions $\left[2-\left(\mathrm{SiMe}_{3}\right)-3-(\mathrm{R})-2,3-\mathrm{C}_{2} \mathrm{~B}_{4} \mathrm{H}_{4}\right]^{2-}(\mathrm{R}=$ $\left.\mathrm{SiMe}_{3}, \mathrm{Me}\right)$ in $n$-hexane, THF, or TMEDA gave the oxidative cage closure product, 1-( $\left.\mathrm{SiMe}_{3}\right)-2-(\mathrm{R})-$ 1,2-closo- $\mathrm{C}_{2} \mathrm{~B}_{4} \mathrm{H}_{4}$ derivatives in 40-59\% yields, along with small quantities of $\mathrm{C}_{4} \mathrm{~B}_{8}$-carborane derivatives; there was no evidence of a persisting nickelacarborane. Platinum salts were found to give the same reductive cage closure reactions. A face-to-face fused $\mathrm{C}_{4} \mathrm{~B}_{8}$ cage product earlier reported by Grimes and coworkers also proceeded from the less thermodynamically stable carbons-adjacent metallacarboranes [20-23]. On the other hand, the reaction of $\mathrm{NiCl}_{2}$ with the carbons-apart, THF-solvated dilithium compound of $\left[2,4-\left(\mathrm{SiMe}_{3}\right)_{2} \text {-nido-2,4- } \mathrm{C}_{2} \mathrm{~B}_{4} \mathrm{H}_{4}\right]^{2-}$ produced a $\mathrm{Ni}(\mathrm{IV})$ complex, commo-1,1'$\mathrm{Ni}\left[2,4-\left(\mathrm{SiMe}_{3}\right)_{2}-2,4-\mathrm{C}_{2} \mathrm{~B}_{4} \mathrm{H}_{4}\right]_{2}$ and $\mathrm{Ni}^{0}$, with no evidence of cage reduction products [24]. In the presence of TMEDA, the Ni(II) half-sandwich 1-(TMEDA)-closo-Ni[2,3-( $\left.\left.\mathrm{SiMe}_{3}\right)_{2}-2,4-\mathrm{C}_{2} \mathrm{~B}_{4} \mathrm{H}_{4}\right]$ was obtained [24]. Reaction of the Ni(IV) complex with moist TMEDA produced 1-(TMEDA)-closo$\mathrm{Ni}\left[2,3-\left(\mathrm{SiMe}_{3}\right)_{2}-2,4-\mathrm{C}_{2} \mathrm{~B}_{4} \mathrm{H}_{4} \text { and 1,2-( } \mathrm{SiMe}_{3}\right)_{2}-1,2$-closo $-\mathrm{C}_{2} \mathrm{~B}_{4} \mathrm{H}_{4}$. This is one of the few instances when the more stable carbons apart undergoes oxidative cage closure. In an effort to better understand the role of the metal and carborane in the reactions involving the late transition metals, a series of fulland half-sandwich metallacarboranes were synthesized from the reactions of $\mathrm{MCl}_{2}(\mathrm{M}=\mathrm{Co}, \mathrm{Fe}, \mathrm{Ni})$ and closo-exo-y, $x-\mathrm{Li}(\mathrm{L})-1-\mathrm{Li}(\mathrm{L})-2, n-\left(\mathrm{SiMe}_{3}\right)_{2}-2, n-\mathrm{C}_{2} \mathrm{~B}_{4} \mathrm{H}_{4}(y=4, x=5, \mathrm{~L}=2$ THF, $n=3(\mathbf{1}) ; y=4, x$ $=5, \mathrm{~L}=$ TMEDA, $n=3(2) ; y=5, x=6, \mathrm{~L}=2 \mathrm{THF}, n=4(3) ; y=5, x=6, \mathrm{~L}=$ TMEDA, $n=4(4))$ in 1:1 molar ratios in benzene. The results are summarized in Schemes 4 and 5 [25]. As seen, with the exception of exo-4,4',5,5'-Fe(TMEDA)-commo-1,1'-Fe[2,3-( $\left.\left.\mathrm{SiMe}_{3}\right)_{2}-2,3-\mathrm{C}_{2} \mathrm{~B}_{4} \mathrm{H}_{4}\right]_{2}$ (7), all commo-metallacarboranes were the results of a redox reaction in addition to a ligation process; the co-product in all these reactions was the respective zero valent metal. The only other redox-free ligation processes were found in the formations of the carbons apart closo-metallacarboranes, 1-(TMEDA)-closo-2,4-( $\left.\mathrm{SiMe}_{3}\right)_{2}$ 1,2,4- $\mathrm{MC}_{2} \mathrm{~B}_{4} \mathrm{H}_{4}(\mathrm{M}=\mathrm{Co}(\mathbf{1 6 a}), \mathrm{Ni}(\mathbf{1 6 b}))$. In both complexes, the metal ions are coordinated to bidentate TMEDA molecules, as well as the more oxidation-resistant carbons-apart carboranes. On the other hand, the carbons-apart carboranes favored a disproportion of $\mathrm{Fe}(\mathrm{II})$ in the formation of commo-1,1'$\mathrm{FeH}\left[2,4-\left(\mathrm{SiMe}_{3}\right)_{2}-2,4-\mathrm{C}_{2} \mathrm{~B}_{4} \mathrm{H}_{4}\right]_{2}(\mathbf{1 4 a})$ and $\mathrm{Fe}(0)$, even in the presence and absence of TMEDA. At present, there is no ready explanation as to why the carbons-adjacent isomer gives the Fe(II) commocomplex (7) while the carbons-apart isomer supports Fe oxidation (14a). The results in Schemes 4 and 5 are consistent with the assumption that all the reactions proceed through an initial formation of a halfsandwich, closo-metallacarborane, which, depending on the metal, carborane, and other ligands present, could be sufficiently stable to be isolated, or could undergo further reaction yielding either fullsandwich, commo-metallacarborane and/or redox products. 

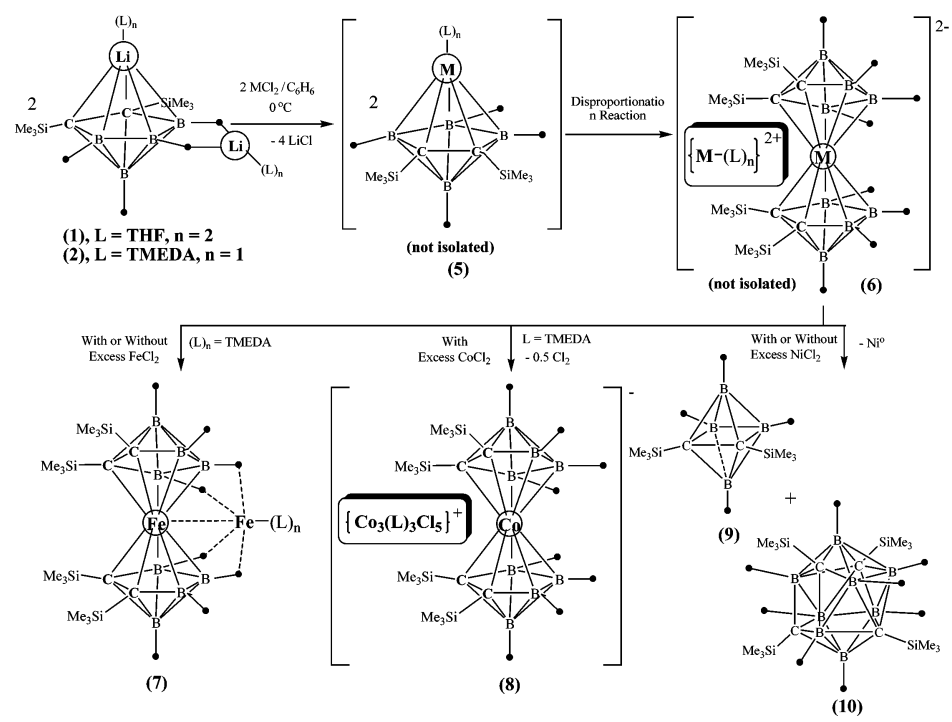

Scheme 4 Reaction of the late transition metals with $\left[2,3-\left(\mathrm{SiMe}_{3}\right)_{2}-2,3-\mathrm{C}_{2} \mathrm{~B}_{4} \mathrm{H}_{4}\right]^{2-}$.

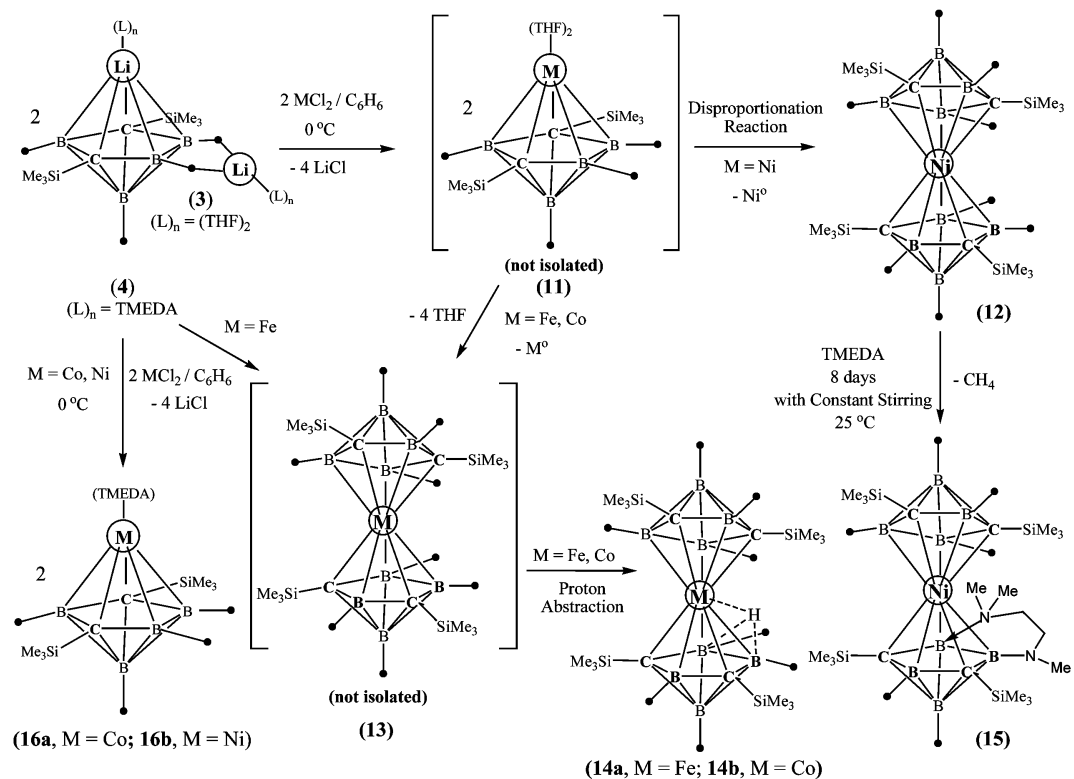

Scheme 5 Reactions of the late transition metals with $\left[2,4-\left(\mathrm{SiMe}_{3}\right)_{2}-2,4-\mathrm{C}_{2} \mathrm{~B}_{4} \mathrm{H}_{4}\right]^{2-}$.

\section{ACKNOWLEDGMENTS}

This work was supported by grants from the National Science Foundation (CHE-0241319), the donors of the Petroleum Research Fund, administered by the American Chemical Society, The Robert A. Welch Foundation (N-1322 to JAM), and Northern Illinois University through a Presidential Research Professorship. N.S.H. gratefully acknowledges the Forschungspreis der Alexander von HumboldtStiftung and the Gauss Professorship of the Göttingen Academy of Sciences. 


\section{REFERENCES}

1. Various authors, in (a) Electron-Deficient Boron and Carbon Clusters, G. A. Olah, K. Wade, R. E. Williams (Eds.), John Wiley, New York (1991) and Pure Appl. Chem. 63 (1991); (b) Contemporary Boron Chemistry, M. Davidson, A. K. Hughes, T. B. Marder, K. Wade (Eds.), Royal Society of Chemistry, London (2000); (c) Borane, Carborane, Carbocation Continuum, J. Casanova (Ed.), John Wiley, New York (1998).

2. R. N. Grimes. In Comprehensive Organometallic Chemistry (COMC I), G. Wilkinson, F. G. A. Stone, E. W. Abel (Eds.), Chap. 5.5, p. 459, Pergamon, New York (1982); (b) R. N. Grimes. In COMC II, E. W. Abel, F. G. A. Stone, G. Wilkinson (Eds.), Chap. 9, p. 373, Elsevier Science, Oxford (1995).

3. (a) N. S. Hosmane, J. A. Maguire. Organometallics 24, 1356 (2005); (b) A. K. Saxena, J. A. Maguire, N. S. Hosmane. Chem. Rev. 97, 2421 (1997).

4. M. F. Hawthorne, D. C. Young, P. A. Wegner. J. Am. Chem. Soc. 87, 1818 (1965).

5. A. R. Oki, H. Zhang, N. S. Hosmane. Angew. Chem., Int. Ed. Engl. 31, 432 (1992).

6. H. Zhang, A. R. Oki, Y. Wang, J. A. Maguire, N. S. Hosmane. Acta Crystallogr., Sect. C 51, 635 (1995).

7. N. S. Hosmane, Y. Wang, A. R. Oki, H. Zhang, J. A. Maguire. Organometallics 15, 626 (1996).

8. C. Zheng, N. S. Hosmane, H. Zhang, D. Zhu, J. A. Maguire. Internet J. Chem. 2, 10 (1999) (URL: <http://www.ijc.com/articles/1999v2/10/>).

9. (a) N. S. Hosmane, Y. Wang, H. Zhang, A. R. Oki, J. A. Maguire, E. Waldhör, W. Kaim, H. Binder, R. K. Kremer. Organometallics 14, 1101 (1995); (b) N. S. Hosmane, Y. Wang, H. Zhang, J. A. Maguire, M. McInnis, T. G. Gray, J. D. Collins, R. K. Kremer, H. Binder, E. Waldhör, W. Kaim. Organometallics 15, 1006 (1996).

10. (a) J. Wang, S.-J. Li, C. Zheng, N. S. Hosmane, J. A. Maguire, H. W. Roesky, C. C. Cummins, W. Kaim. Organometallics 22, 4390 (2003); (b) J. Wang, S.-J. Li, C. Zheng, A. Li, N. S. Hosmane, J. A. Maguire, H. W. Roesky, C. C. Cummins, W. Kaim. Organometallics 23, 4621 (2004).

11. S. Kraut, J. Magull, U. Schaller, M. Karl, K. Harms, K. Dehnicke. Z. Anorg. Alleg. Chem. 624, 1193 (1998).

12. (a) O. I. Shchegolikhina, Y. A. Pozdniakova, S. V. Lindeman, A. A. Zhdanov, R. Psaro, R. Ugo, G. Gavioli, R. Battisuzzi, M. Borsari, T. Rüffer, C. Zhcchi, G. Pályi. J. Organomet. Chem. 514, 29 (1996); (b) A. W.-H. Lam, W.-T. Wong, G. Wen, X.-X. Zhang, S. Gao. New J. Chem. 25, 531 (2001).

13. K. Yunlu, P. S. Gradeff, N. Edelstein, W. Kot, G. Shalimoff, W. E. Streib, B. A. Vaartstra, K. G. Caulton. Inorg. Chem. 30, 2317 (1991).

14. (a) R. D. Ernst. Acc. Chem. Res. 18, 56 (1985); (b) R. D. Ernst. Chem. Rev. 88, 1255 (1988); (c) M. E. N. Clemente, P. J. Saavedra, M. C. Vasquez, M. A. Paz-Sandoval, A. M. Arif, R. D. Ernst. Organometallics 21, 592 (2002); (d) V. Kulsomphob, A. M. Arif, R. D. Ernst. Organometallics 21, 3182 (2002); (e) F. H. Köhler, R. Molle, W. Strauss, B. Weber, R. W. Gedridge, R. Basta, W. Trakarnpruk, R. Tomaszewski, A. M. Arif, R. D. Ernst. Organometallics 22, 1923 (2003).

15. J. R. Bleeke. Chem. Rev. 101, 1205 (2001).

16. U. Effertz, U. Englert, F. Podewils, A. Salzer, T. Wagner, M. Kaupp. Organometallics 22, 264 (2003).

17. A. Li, J. Wang, C. Zheng, J. A. Maguire, N. S. Hosmane. Organometallics 23, 3091 (2004).

18. J. Wang, G. Canseco-Melchor, C. Zhang, J. A. Maguire, N. S. Hosmane. Organometallics. Submitted for publication.

19. N. S. Hosmane, A. K. Saxena, R. D. Barreto, H. Zhang, J. A. Maguire, L. Jia, Y. Wang, A. R. Oki, K. V. Grover, S. J. Whitten, K. Dawson, M. A. Tolle, U. Siriwardane, T. Demissie, J. S. Fagner. Organometallics 12, 3001(1993). 
20. (a) W. M. Maxwell, V. R. Miller, R. N. Grimes. Inorg. Chem. 15, 1343 (1976); (b) R. B. Maynard, R. N. Grimes. J. Am. Chem. Soc. 104, 5983 (1982).

21. H. A. Boyter Jr., R. N. Grimes. Inorg. Chem. 27, 3075 (1988).

22. R. N. Grimes. Adv. Inorg. Radio. Chem. 26, 55 (1983).

23. J. R. Pipal, R. N. Grimes. Inorg. Chem. 18, 263 (1979).

24. H. Zhang, Y. Wang, A. K. Saxena, A. R. Oki, J. A. Maguire, N. S. Hosmane. Organometallics 12, 3933 (1993).

25. S. Tomlinson, C. Zheng, N. S. Hosmane, J. Yang, Y. Wang, H. Zhang, T. G. Gray, T. Demissie, J. A. Maguire, F. Baumann, A. Klein, B. Sarkar, W. Kaim, W. N. Lipscomb. Organometallics 24, 2177 (2005) 